\title{
Complex complementizers and the structural relation with weak $T$ - New (morpho)syntactic data from a Pomeranian language island in Brazil
}

\author{
Gertjan Postma (Meertens Institute Amsterdam)*
}

\begin{abstract}
In this paper I discuss three properties of Brazilian Pomeranian, a Germanic language spoken in Espirito Santo, Brazil by descendents who emigrated in the $19^{\text {th }}$ century. These three aspects of the verbal system are: 1 . The relation between complex complementizers, a twoinfinitive system, and split infinitives, previously discussed in Van Gelderen $(1993,1998)$ and Schallert (2012, 2013), 2. Verb Projection Raising (VPR), as discussed by Van Riemsdijk 2002, Haegeman 2007, Salzmann 2011, and Brandner \& Salzmann 2012, and 3. Verb-Second positioning of verbal clusters, previously discussed in De Vos (2005). I discuss novel Pomeranian data from the perspective of the literature on these three topics, which have been thus far studied largely separately from one another. An integrated discussion sheds light on the nature and the proper analysis of these three phenomena. I argue that these phenomena are caused by the "weaknesses" of $\mathrm{T}$. The weakness of $\mathrm{T}$ can be resolved "downward" by copying features onto $T$ under selection by a higher head (AGREE), or can be resolved "upward" under head movement of $\mathrm{T}$.
\end{abstract}

Keywords: complementizer, Germanic, infinitival prefix, do-support, tense, defectiveness

\section{European Pomeranian and the Complementizer System}

\subsection{Introduction}

In the literature there have been two different interpretations of the Continental Germanic infinitival marker $z u / z^{\prime} /$ to/tau/te. According to some researchers, it is a verbal prefix which is inserted late in the derivation (in the post-syntax or at PF, Wurmbrand 2001) or rather low in the tree, or even without a syntactic head (Abraham 2004), or as VP internal process (Haider 1993, 2003). Alternatively, it has been analyzed as a morpheme that marks a certain VP external functional projection, say T, that is syntactically active (Bennis \& Hoekstra 1984, Koster \& May 1982, Sabel 1996, IJbema 2002). Brandner (2006) argues that there are two infinitival markers in standard German, one superfical $z u$, which we call IM1. This can be easily absent or dropped. There is another syntactically active $z u$, which we call IM2. While these markers are not overtly distinguisable in Standard German, they are overtly different in Alemannic, where IM1 is zero, while IM2 is lexical. The situation in Pomeranian is similar to Alemannic: only IM2 is lexical. In this paper we study the syntactic activity of IM2 in Pomeranian and link its syntactic behaviour (it undergoes T-to-C) to other syntactic properties, such as cluster-V2, apparent Verb projection raising, do-support, and absence of $\mathrm{V}$-to-T (no regular past tenses).

\footnotetext{
* This paper is spinoff of a project in collaboration with Elizana Schaffel Bremenkamp, Andrew Nevins and Kathy Rys on Dutch (Zeeuws-Flemish dialect) spoken in Brazil in the state of Espirito Santo. We soon realized we had to study Pomeranian, as the Dutch dialect spoken in the Pomeranian area is - for some speakers- strongly influenced by Pomeranian. I thank Elizana Schaffel Bremenkamp and Tereza Gröner Schaffel for all judgements they provided on Brazilian Pomeranian. I thank Ismael Tressmann for providing the book with traditional narratives and for the discussion on various points, and Martin Salzmann for discussion on the Alemannic data. I am grateful to Elly van Gelderen en Thilo Weber for their comments on an earlier version of this paper. A special thank to Andrew Nevins for the energetic company during the fieldwork and for comments on a previous version. All errors are mine.
} 


\subsection{European Pomeranian}

Pomeranian is the coastal dialect (or set of dialects) of Continental Germanic between the Oder river and the Vistula river, an area which is called Hinter-Pommern. Until 1945 it was part of Germany, but lays in present-day Poland. The dialect of Vor-Pommern/Mecklenburg in present-day Germany is quite different and should be discussed separately from HinterPommersch, henceforth simply Pomeranian. In the map below, slightly adapted from Brockhaus 2012:128), we give an impresssion of the Pomeranian area, indicated with 'Ostpommersch'.

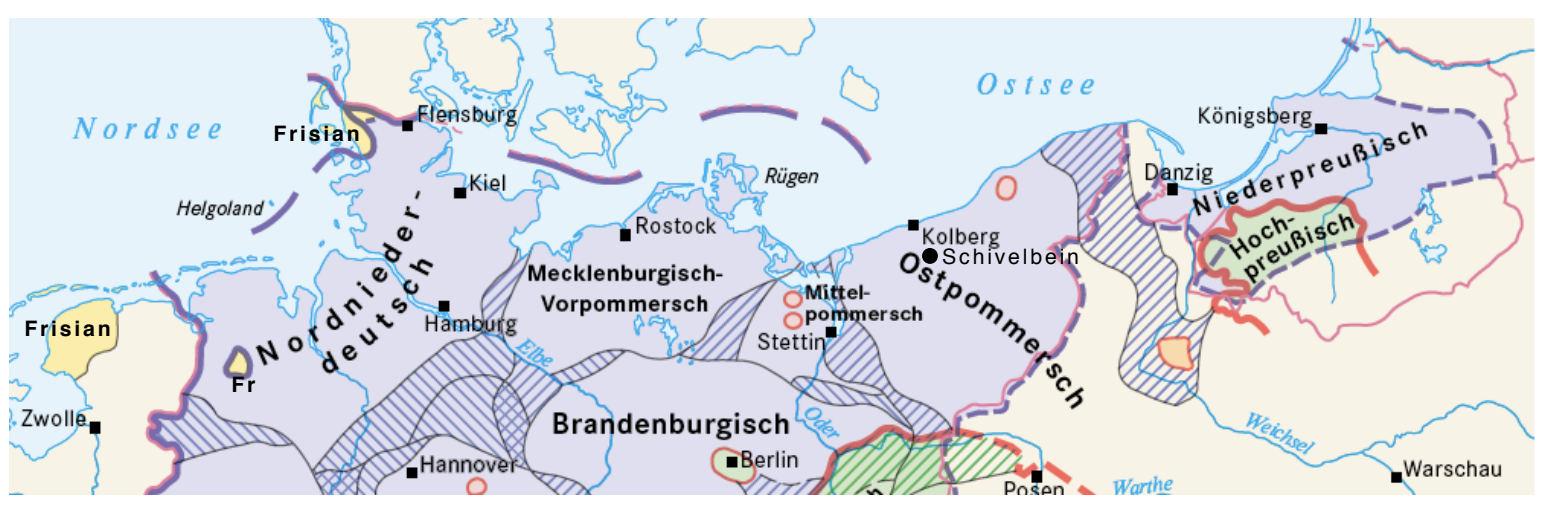

A distinguishing feature of the Pomeranian verbal system is the existence of two infinitival forms: an infinitive in -a ([ə] or [e]), and one in -en ([ən] or [n] , Wiesinger 1983, karte 47.14, Wrede 1895:295), a property we also encounter in Coastal Germanic languages such as WestFrisian Dutch dialects, Frisian and North Frisian (Hoekstra 1997: 4-5). ${ }^{1}$ In Pommeranian embedded clauses without a complementizer, such as under modals, causatives (lata 'let'), daua 'do', verbs of motion ( $g a a^{\circ}$ 'go'), and control predicates, the infinitive in - $\boldsymbol{a}$ is used, which we call infinitive-I, or simply "infinitive", as exemplified by the Wenker-sentence ${ }^{2} 16 \mathrm{~b}$ in (1), taken from location 20, the village of Schloenwitz (Slonowice) in the municipality Schivelbein (see map).
European Pomeranian, 19th century (Schloenwitz, loc. 20)
du must eista no 'a inn wass-a
you must first still a bit grow.inf
'you must first still grow a bit'

The infinitive in -en, which we will call infinitive-II or "gerund", is typically used in embedded infinitivals with a leading complementizer, as exemplified in the Wenker-sentence $16 \mathrm{a}$ in (2), again taken from the village of Schloenwitz.

European Pomeranian, 19th century

du bust nog ni groot naug um 'n Flasch Wiin ut-tau-drink-en

(Schloenwitz)

you are yet not big enough COMP a bottle wine PRT-to-drink.gerund

'you are not big enough to drink out a bottle of wine'

\footnotetext{
${ }^{1}$ Alemannic dialects also have two infinitival forms, one in -a/e and one in -i(n)t (Bayer \& Brandner 2004). The syntactic distribution is quite different from the -a/e vs -en infinitive in Coastal Germanic.

${ }^{2}$ The Wenker-sentences are a set of 40 sentences that Georg Wenker used in a questionnaire for dialect research in 1880 in 40,000 locations in Germany. The sentences have also been elicitated in The Netherlands, Belgium, Luxemburg, Austria, and Switzerland.
} 
There is some variation in the realization of this construction in European Pomeranian with respect to the infinitival prefix tau 'to'. Apart from (2) where, as in Standard German, Dutch and Frisian, both $u m$ and tau are realized, (e.g. $u m$ and $z u$ in German, om and te in Dutch/Frisian), we observe two alternative patterns in Pomeranian. In one of these, the 'to'prefix tau remains unrealized (3b), and in another variant, um, the 'for' complementizer, remains unrealized $(3 \mathrm{c}) .^{3}$

\section{European Pomeranian, 19th century}

a. du bust nog nich grot naug um an Flasch Wiin ut-tau-drinken (Schloenwitz)

b. du bust nog nich grot naug um an Flasch Wiin ut-ø-drinken (Lankow, 140)

c. du büst no ni groot naug $\boldsymbol{\emptyset}$ ain Flasch Winn ut-tau-drinken (Schlenzig, 223) you are yet not big enough COMP a bottle wine PRT-to-drink.gerund 'you are not big enough to drink out a bottle of wine'

The fourth possible option with both um 'for' and tau 'to' unrealized, is not found. We summarize the patterns in (4) for the Schivelbein area ${ }^{4}$ and from the entire coastal area. ${ }^{5}$ From now on we will gloss $u m$ as 'for' and tau as 'to'.

$\begin{array}{lclll} & \text { Pattern } & \text { Occurrence } & \text { Schivelbein } & \text { Pomerania } \\ \text { a. } & \text { for .... to } & \text { general } & 30 & 258 \\ \text { b. } & \varnothing \ldots . \text { to } & \text { rare } & 6 & 34 \\ \text { c. } & \text { for ..... } & \text { rare } & 4 & 20 \\ \text { d. } & * \varnothing \ldots . . \varnothing & - & - & -\end{array}$

The complementizer $u m$ 'for' can remain empty only if the verbal prefix tau 'to' is not empty; conversely, the verbal prefix tau can be empty only if the complementizer um is not. We conclude that both positions must "see" each other at some level of representation ((Bennis \& Hoekstra 1984:55). This suggest that the tau-marker in Pomeranian, at least in these rationale clauses, concern the syntactic type of the infinitival marker as described in Brandner 2006, i.e. IM2. Following standard assumptions on these markers, we assume that for (um, om, üm ...) sits in C (Koster \& May 1982:133, Vanden Wyngaerd 1987:108) and to (zu, te, to, tau, ...) sits in T (Evers 1990, Sabel 1996). ${ }^{6}$ Since we are dealing with constructions that have a lexicalized complementizer in continental Germanic, we assume that there is T-to-C movement at some level of representation and that the complementizer $\mathrm{C}$ must have an overt realization in European Pomeranian. We therefore assume the assumptions in (5), taken from Hoekstra ([1992]1997:106,116) developed for (Fering) Frisian. The lexicalization

\footnotetext{
${ }^{3}$ These are not necessarily different dialects, as optionality might be involved, as in the standard Dutch complement clause in (i) where the complementizer is optionally realized.

(i) ik beloof je om/ø wat eerder weg te gaan

I promiss you COMP somewhat earlier away to go

${ }^{4}$ We investigated the 43 locations in the Schivelbein-area, of which 40 display useful data. The pvalue (Pearson's) is 0.24 . We chose the Schivelbein dialects because these are closest to Brazilian Pomeranian. (We thank Jeffrey Pheiff for performing a rough localization using a few dialect cues).

${ }^{5}$ More than 300 locations in Pomerania were checked (in the regions Schivelbein, Regenwalde, Belgard, Colberg-Cörlin, Cöslin, Greifenberg, Schlawe). This wider area proves a structural absence of the $[\varnothing \ldots \varnothing]$ pattern with p-value of 0.09 . To be more precise: The hypothesis $\mathrm{H}_{0}$ that the absence of the $\varnothing \ldots . \varnothing$ pattern is a mere result of the (low) Probablitity $(\mathrm{FOR}=\varnothing) \cdot$ the (low) Probability $(\mathrm{TO}=\varnothing)$ is rejected with a p-value of 0.09 .

${ }^{6}$ Bennis (1986) argues that so-called prepositional adjunct clauses have $\mathrm{P}$ in the $\mathrm{C}$ position.
} 
requirement of $\mathrm{C}$ already holds in West Germanic for main and embedded finite clauses and $(5 b)$ is a natural extension to non-finite sentential constructions.
a. $\quad \mathrm{C} \ldots . . \mathrm{T} \quad \Rightarrow \quad \mathrm{C}^{\circ}[\mathrm{C}+\mathrm{T}] \ldots \ldots . \mathrm{T}$
b. Pomeranian
$\left[\mathrm{C}^{\circ}\right]$ is overt in all types of clauses ${ }^{7}$

In the rest of the paper we will provide evidence that these assumptions also hold in Brazilian Pomeranian.

Apart from this verbal use of the gerund, there is also a nominalized use of the -en form, as for instance in Wenker sentence 20, given for Schloenwitz in (6).

$$
\begin{aligned}
& \text { European Pomeranian, 19th century } \\
& \text { Hai deer so, as hann-e in taum dörsch-en bistellt } \\
& \text { He did so, as if had he him for-the.DAT threshing invited } \\
& \text { '...as if he had invited him for the threshing' }
\end{aligned}
$$

(Schloenwitz)

In this construction, tau is a preposition enriched with a dative marker (taum $<\operatorname{tau}+(\mathrm{de}) \mathrm{m})$. This construction allows adjectival modification but no direct object arguments between taum and the nominalized verb which does not assign accusative case. These properties of 19th century European Pomeranian may serve as a background when we describe Brazilian Pommeranian in the next section.

\section{Brazilian Pomeranian and Split Infinitives}

While Pomeranian is not used anymore in cohesive communities in Europe since 1945, it is still in full use in various parts of Brazil, with many children not learning Portuguese at all until schooling at age six or so. These communities derive from immigration as early as 1850 , and have been rather isolated until recently. In this article we will use the variant spoken in the state of Espirito Santo, in the municipality of Santa Maria de Jetibá and the surrounding environment. We simply call it Brazilian Pomeranian, though there might be differences with the variants in the South (in the state of Rio Grande do Sul). Recently, a dictionary of Brazilian Pomeranian was published (Tressmann 2006b), as well as a collection of tales un the title Upm Land (Tressmann 2006a, henceforth $U m L$ ). The data used in this paper are mainly from this corpus of tales, provided by a variety of authors and registered by Anivaldo Kuhn and Ismael Tressmann. The orthography that is used is the one developed in Tressmann (2006ab). Apart from this corpus ${ }^{8}$ we completed our data by two interviews in March 2013 (Elizana Schaffel Bremenkamp) and September 2013 (Elizana Schaffel Bremenkamp and Tereza Gröner Schaffel).

The distinction between the two infinitives has been retained in Brazil. The complementizer, however, is not realized as um, but as taum ([ $\left.\left.\operatorname{ta}^{\mathrm{u}} \mathrm{m}\right] /[\mathrm{tam}] /[\mathrm{tom}]\right)$. Interestingly, the verbal prefix is always null, indicated with ø. We give some examples in (7), rationale clauses, taken from $\operatorname{UmL}(78,114,115)$.

\footnotetext{
${ }^{7}$ It would be attractive to extend this to West Germanic infinitivals without $u m$ in general, as in Bayer (1984). We only defend the claim for Pomeranian here. Kayne (1999) argues that all Romance complementizers are complex: a $\mathrm{W}$ head that have attracted the infinitival prefix $d i$.

${ }^{8}$ The book was scanned and OCRed. We used the uncorrected OCR in our statistics. We used the original hardcopy in all example sentences. The book contains 54 tales of around two-page length. In order to facilitate searching, we retained the orthography used in Tressmann 2006a, even when there are occasional mistakes, such as /muida/, for [mu'ta] or if Tressmann abandoned his earlier convention (Tressmann, pers. comm), as in the case of the infinitive in -a for -e.
} 


\section{Brazilian Pomeranian}

a. Dai lüür sin arm un häwa kair gild [taum sich air huus ø buugen]. The people are poor and have no money for-to REFL a house ø build.gerund 'The people are poor and have no money to build themselves a house'

b. Dai blaumasuuger is air seir hübsch tijr. Hai hät aine lang snåbel [taum dai saft uuta blauma $\boldsymbol{\varnothing}$ suugen].

The flowersucker (hummingbird) is a very elegant animal. He has a long bec for-to the juice out-the flowers suck.gerund

c. Dai ima maga seir geirn dai maluulabüsch eer blauma [taum sich eera hoinig o måken].

the bees like.pl very much the malula bushes their flowers for-to REFL their honey make.gerund

'The bees like the malula-bushes's flowers very much to make honey'

This construction seems to be a combination of the verbal construction in (2) and the nominal taum-construction in (6): it combines the full verbal behaviour of (2) and the possibility of having lexical material between tau and the nominalized verb in (6). One way of understanding this innovation is to postulate that Brazilian Pomeranian has reanalyzed taum, which was originally a $\mathrm{P}+\mathrm{CASE}$ complex $[\mathrm{tau}+\mathrm{m}]$, into [tau+um], i.e. as a $\mathrm{C}+\mathrm{T}$-complex. It is then an overt realization of the rule in (5) that we inferred from European Pomeranian. We can compare this construction with the Middle-English split infinitive (where the verbal prefix to has undergone T-to-C in forming a complex for-to complementizer (8), taken from Visser (1963 par. 982), see also Mustanoia (1960).

\section{Middle English}

a. A nurish or a modir is not bounde forto alwey and for euere $\boldsymbol{\varnothing}$ fede her children

'a nurse or a mother is not bound to always and for ever feed her children'

(Pecock, Repr. 219)

b. He eoden (...) forto fully that folk and godes lawe o techen

(ibidem)

he went ..... for-to fuly teach that people and god's law

'he went in order to fully teach god's law to that people'

(zeugma!)

c. if it schulde plese god forto bi miracle $\boldsymbol{\varnothing}$ make a fier and a watir togidere if it should please god for-to by miracle make a fire and a water together 'if it would please go to combine fire and water'

(ibidem)

It is not clear whether the split-infinitive-II construction in (7) is a Brazilian innovation. It does not occur in the 19th century Wenker material, at least not in the Pomeranian area. But it does occur in the Wenker material in the Alemannic dialects of Switzerland and Austria (Vorarlberg), as illustrated in (9a) and (9b), respectively.

Alemannic, 19th century (Fläsch, Graubünden, 42974 \& Krumbach, 42815)

a. du bisch noh z Klii zum a Fläscha Wi us-ø-trinka

b. du binscht no nit gros gnug, zum a flöscha wing us-ø-trinken

you are yet not big enough COMP a bottle wine PRT-to-drink.gerund 'you are not big enough to drink out a bottle of wine'

Intermediate constructions also occur, where the verbal to-prefix doubles. 
Alemannic, 19th century (Schröcken, 42883)

du bischt no ned groß gnua, $\mathbf{z}$ ' uma Fläscha Wi us $\mathbf{z}^{\prime}$ 'trinchä $^{9}$

you are yet not big enough COMP a bottle wine PRT-to-drink.gerund

'you are not big enough to drink out a bottle of wine'

We might take this as direct evidence of a movement chain of T-to-C. In this case two copies of $\mathrm{T}$ are spelled out, which allows for the nonrealization of um. ${ }^{10}$ We refer to Bayer \& Brandner (2004), Schallert (2012) for further data in Schwaben, Switzerland and the Vorarlberg that speaks to this issue. ${ }^{11}$

Direct influence of Alemannic on Brazilian Pomeranian is improbable. ${ }^{12}$ There is also the possibility that the split-infinitive-II construction is native from Pomerania. In Stritzel (1937:69), a Pomeranian grammar from the 1930's, a similar construction for the village of Grossendorf $^{13}$ is reported, given in (11). Furthermore, there is at least one example (an idiomatic expression) in a Pomeranian dictionary (cf. 11b, taken from Laude \& Dorries 1995).
European Pomeranian (20th century, before 1945)
a. dan is de seinste tiid [tum draxen stiijen $ø$ louten] then is the nicest time to drake rise let.inf
'then it is the best time to let climb the dragon/kite'
b. dat is jå tam up d' boim kleppere $^{14}$
that is PRT for-to upto the tree climb.inf
(Grossendorf, 52858)
'that is to become desperate'

Furthermore, the construction is found in a Low-German recording from Pella (Wisconsin, USA), available from the Databank für Gesprochenes Deutsch. Though without metadata documentation, the recording seems Pomeranian, and the transcription of the same Wenker sentence 16 in (3), (9), and (10) in this variety is informally presented in (12). ${ }^{15}$

\footnotetext{
${ }^{9}$ We retain the original transcription $z^{\prime}+u m a$ on the Wenkerbogen here, though it should be analyzed as zum $+a$ (Martin Salzmann, pers. comm.).

${ }^{10}$ In the Pomeranian area that was checked (the regions Schivelbein, Regenwald, Belgard, ColbergCörlin, Cöslin, Greifenberg, Schlawa), we found one case of this type:

(i) Du büst no nie grot nouch to ne Flasch Wiin ut tau drinken Altschlage is Sława (Świdwin)). It used to be a Wendish settlement.

11 A similar construction is reported in Swabian (Müller 1996, cited in Hoekstra 1997:23), who analyzes the floating 'to' as head movement to $\mathrm{C}$ or to Asp.

(i) dass'r extra hoimkomma isch [ zom schnell des Päckle aufmacha]

(ii) dass'r mir a weng Zoet brauchat [ zom des neie Haus en dr Garteschtross en Tiebenga zom/z' baua ]

(iii) dass'r kurz [den Zättl zom aus zom/z' fülla ] og fanga hat.

${ }^{12}$ Though there is a Swiss community Suiça in the Pomeranian area in Espirito Santo, its earliest immigration to the Santa Leopoldina area consisted of 30 Catholic families (Franceschetto 2004:155). The Pomeranian community and the Suiça community were segregated by religion: Lutheran versus Catholic. In 1860, there was a huge Catholic church in the center of the area, and a small Protestant chapel at the edge, which were in conflict to a point that the governor of the state had to intervene (Tschudi 1860:139). There is also Colônia Tirol nearby, which might have had influence (Ingeborg Geyer, pers. comm.).

${ }^{13}$ Present-day Wielka Wieś (Pomeranian Voivodeship).

${ }^{14}$ Notice the infinitival form in -e. This also happens in Brazilian Pomeranian in bisyllabic roots: e.g. in -ijre and -(e)re.

${ }^{15}$ IDS database, http://dgd.ids-mannheim.de. File MV--_E_00136_SE_01_A_01_DF_01.WAV, time 00:01: 54.35 .
} 


\author{
Wisconsin Pomeranian (DGD-IDS, MV-E136) \\ du büs no ni groot nôch tau ain flash wiin ut-ø-drinke \\ you are yet not big enough COMP a bottle wine PRT-to-drink.gerund \\ 'you are not big enough to drink out a bottle of wine'
}

Notice that $\mathrm{C}$ is lexicalized with simple tau rather than taum and, secondly, that the verbal form is in $-e$, i.e. the simple infinitive. So, either it is not (Hinter)Pomeranian, or there has been neutralization of the two infinitival forms in the USA. These data feed the idea that the split infinitive-II originates from Europe. However, as T-to-C is, by hypothesis, a formal option of UG that can arise spontaneously, we should not exclude the possibility that the split taum $+\mathrm{V}$-en construction has arisen as a consequence of language contact between Germanic and a variety of non-Germanic: Germanic, having both $\mathrm{C}$ and a to-prefix, and languages without such a prefix, like Romance and Slavic, which only have a $\mathrm{C}$ infinitival marker (e.g. de). In all these places where Germanic has developed split-infinitives, language contact is well-established: Pomeranian and Modern English (in Pella), Pomeranian and Slavic (Kashubian \& Slovincian) in Pomerania, Pomeranian and Portuguese (in Espirito Santo), Alemannic and Romance (in Switzerland); however, more research is needed here.

So what is the synchronic analysis of the split-infinitive-II construction in (7), repeated here as (13)?

Dai lüür sin arm un häwa kair gild [taum sich air huus ø buug-en]

The people are poor and have no money for-to themselves a house $\varnothing$ build.gerund

'The people are poor and have no money to build themselves a house'

The idea is that the material between the taum $(=t a u+u m) \mathrm{C}+\mathrm{T}$ complementizer and the infinitive-II is evidence for movement of the tau from $\mathrm{T}$ to $\mathrm{C} .{ }^{16}$ The split infinitive construction is motivated by the need for T-to-C movement. Brazilian Pomeranian is unique among the Germanic languages in light of the patterns in (4), repeated below as (14), which the others do not resolve by overt movement of non-finite $\mathrm{T}$. The assumption is than that Brazilian Pomeranian realizes the missing link: ${ }^{17}$
a. for ..... to
b. $\quad \varnothing \ldots \ldots . .$. to
c. for ...... Ø
d. $\quad * \varnothing \quad \ldots \ldots . \varnothing$
e. fortto ... $\varnothing$
general in European Pomeranian
rare in European Pomeranian
rare in European Pomeranian
$-$
Brazilian Pomeranian

To sum up the discussion of the taum- $+\mathrm{V}$-en (split-infinitive-II) construction in Brazilian Pomeranian: its behaviour can be described as movement of T-to-C i.e. as a need to

\footnotetext{
${ }^{16}$ As said in footnote 4, Hoekstra ([1992]1997: 106 and 116) forwards this assumption for (Fering) Frisian "sentential to-infinitives". Frisian "sentential to-infinitives" (Frisian and Fering Frisian alike), however, are not fully sentential as they do not allow for negation, do not license accusative objects, and do not obviously lexicalize C. Pomeranian tam-constructions are sentential as to lexicalizing $\mathrm{C}$, permitting objects, and allowing for the sentential negative marker $n i$ 'not' and floating quantifiers.

(i) Den waard dai gumi ain par dag ina fluss rinermakt [taum ni sward waaren]

Then is the gum once per day in-the liquid in-put.ptc [for (it) not to become black]

Hoekstra de facto develops a theory of Brazilian Pomeranian rather than of (Fering) Frisian.

${ }^{17}$ Modern Alemannic rationale constructions cover the entire European + Brazilan Pomeranian spectrum (Ellen Brandner, pers. comm).
} 
strengthen T. Informally, we will call this need the "weakness of T". In the next sections, we describe four other typical properties of Brazilian Pomeranian and we will investigate to what extent these properties can be accounted for along similar lines.

\section{Apparent Verb Projection Raising in Pomeranian}

A second property of Brazilian Pomeranian is the apparent occurrence of Verb Projection Raising (Den Besten \& Edmonson 1983, Haegeman \& Van Riemsdijk 1986, Brandner \& Salzmann 2013). Let us first observe that the verbal domain in Brazilian Pomeranian is basically OV, i.e. the complements are realized preverbally. This is exemplified in (15a) where a simple object complement weitbroud is realized to the left of the verb gaiw 'gave', and in (15b) with a complement clause to the left of the hierarchically higher verb hät 'has'.
Brazilian Pomeranian
a. ...dat dat blous tau Wijnachta weitbroud gaiw
that it only at Chrismas wheat-bread gave
'that at Christmas there was only wheat-bread'
b. $\quad$... wen hai dai geschenka ala afgeewt hät when he the gifts all off-given has
'... when he has delivered all the gifts'

(UmL:13)

(UmL:14)

In many constructions, this basic pattern is disturbed by a variety of operations, such as V2 and inversion in verbal clusters. In this respect, Brazilian Pomeranian is a true daughter of continental Germanic. Verb Raising (VR) and Verb Projection Raising (VPR) are theoretical tools to account for head-complement structures in a language that has otherwise predominantly complement-head orders. In $(16 a, b)$ (taken from the first interview and UmL:64, respectively), we present Pomeranian deviations from the basic complement-head pattern. These specific deviations do not occur in German, Dutch, and Frisian, but do occur in West-Flemish (Haegeman \& Van Riemsdijk 1986) and Alemannic (Van Riemsdijk 2002). Let us inspect $(16 a, b)$, in which the modal assumes a participial form underneath the auxiliary have (hence the notation-IPP, to be explained below).

$\begin{array}{lll} & \text { Brazilian Pomeranian } & \\ \text { a. } \quad \text { ik ha müst [dat bauk lè:sa] } & \text {-IPP } \\ \text { I have must.ptc the.n book read.inf } & \\ \text { 'I had to read that book' } & \\ \text { b. } \quad \text { Wij häwa ous müst [seir kwääla dårmit]. } \\ \begin{array}{l}\text { we have us must.ptc very-much torture therewith } \\ \text { 'we must have tortured ourselves with it' }\end{array}\end{array}$

In (16a), the modal müst does not show up after lè:sa, as one would expect from a basic OV order, as Frisian and German display in (18ab), but before it. Similarly, the modal must in (16b) does not show up after its selected complement, but before. So, either the modal head raises to a higher position which is before the complement, or the entire complement-VP undergoes extraposition to the right. These two options are shown in (17a) and (17b) respectively. 


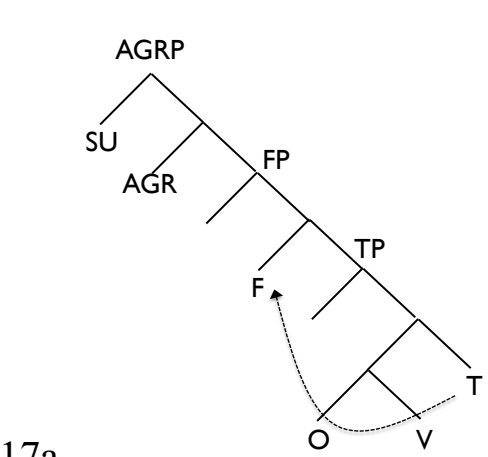

$17 \mathrm{a}$.

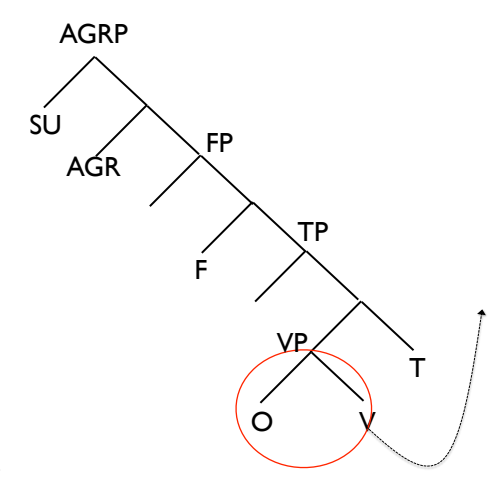

c.

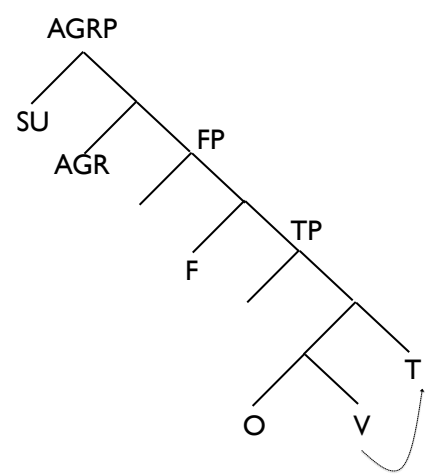

The latter explanation is more widespread in the literature, has been given the name as Verb Projection Raising (VPR). The first explanation by head movement is advocated in Haegeman (2007) and is the more simple one: it has two unproblematic assumptions: headmovement (HM) and movement to the left. But both approaches are possible in principle. So, we have two accounts of "VPR": 1. HM to the left (17a) or 2. VPR to the right (17b). We do not discuss the adjunction slot here as we focus on the structure in (17a).

Apart from this syntactic operation, there is a morphological dimension that cannot be left undiscussed. This can be observed in verbal clusters as in (18). In those clusters, head movement of the lexical verb $\mathrm{V}$ to $\mathrm{T}$ may apply, as illustrated in (17c).
a. Ik ha dat boek lêze kind
I have that book read.inf can.ptc
b. Ich habe das Buch lesen müssen
I have that book read.inf. must.inf
c. Ik heb dat boek moeten lezen
I have that book must.inf read.inf
d. ich hä muese das Buech läse
I have must.inf that book read

$\begin{array}{llc}\text { Frisian } & \text {-IPP } & - \\ \text { German } & +\mathrm{IPP} & \mathrm{VR} \\ \text { Dutch } & +\mathrm{IPP} & \mathrm{VR} \\ \text { Alemannic } & +\mathrm{IPP} & \mathrm{VPR}\end{array}$

Notice that despite the equal order in Frisian and German in (18a,b), they differ in the form of the modal, which is a participle in Frisian (as expected underneath the auxiliary have), but an infinitive in German. In (18c) we see the deviant Dutch order with an infinitive as in German. It is standardly assumed that the change of the participle into an infinitive (+IPP) is a byproduct of verb raising (Evers 1974, Vanden Wyngaerd 1994). If so, then verb raising (of the form in (18b)) is executed string vacuously in German and overtly in Dutch. In (18d) we give the pattern for Alemannic, which is similar to the Brazilian Pomeranian structure in (16a). It is important to notice, though, that Pomeranian has a participle here, while Alemannic has an infinitive. Brazilian Pomeranian is, therefore, more like Frisian enriched with "VPR", while Alemannic (and West-Flemish) are more like German/Dutch enriched with "VPR". It would, of course, be attractive to link the difference in IPP morphology to differences in the type of VPR they undergo. Before we will choose between the two basic theoretical implementations of VPR, true VPR and HM, it is important to introduce yet another dimension in which Brazilian Pomeranian is special. 


\section{V2 of verbal clusters}

Despite many similarities between Frisian and Pomeranian ${ }^{18}$, there is an important difference between these two northern variants of West Germanic. Pomeranian allows for V2 of verbal clusters, which is impossible in Frisian, and - to our knowledge - to any other dialect of West Germanic. Only Afrikaans displays this feature, though with fundamentally different verbs (De Vos 2005). ${ }^{19}$ We provide two instances of this phenomenon in Brazilian Pomeranian in (19-20).
Brazilian Pomeranian
a. Dun [hät küüt] hai sijn leewstijd im schata rijra. Then has could.ptc he his life.time in-the shadow ride 'Then he could drive his whole life in the shadow'
b. Dun [hät müst] papa sou seir loupa, ... then has must.ptc daddy so much run.inf 'Then, daddy had to run so much'

(UmL:42)

(UmL:103)

We see that a verbal cluster (hät küüt, hät müst) is realized between a fronted constituent dun 'then' in the topicalization position and the pronominal or subject (hai, papa). These clusters are not interruptible. ${ }^{20}$ It is not excluded that the sentence in (16) subsumes this pattern with the auxiliary and modal. Cluster V2 only occurs with two auxiliaries, not with HAVE + a causative verb (20c), nor with auxiliary + lexical verb (20d). In that case, the auxiliary undergoes $\mathrm{V} 2$ alone.

(20) a Air häw ik mij na huus nooma

(UmL:106) one have I me to house taken

'I have taken one home for me'

b. Darweegen schala wij kair drek ina fluss smijta therefore shall.pl we no dirt in-the river throw 'therefore we must not throw dirt in the river'

c. Dun häwa (*låte) sai em le:ze (låte)

(elicitated) then.past have (let.ptc) they him read (let.ptc)

'Then they let.past him read'

d. Ik gå (*haale) wåter (haale)

(elicitated)

I go (search.inf) water (search.inf)

'I go search for water'

Apparently, the highlighted verbs in (19) form a cluster at some point of the derivation and

\footnotetext{
${ }^{18}$ Apart from sharing the two-infinitive property, Frisian and Pomeranian are similar in having no geprefix and no Infinitive-pro-Participio (IPP) effect, as well as complementation with pseudo coordination ('try and go', 'start and do', .. for 'try to do').

${ }^{19}$ In Afrikaans, it only happens in modals/aspectual + infinitive clusters.

(i) Waarom kom eet Jan by ons?

why come eat John at us

'Why does John come and eat at our place'?

In Pomeranian it only occurs in clusters of perfect auxiliary + modal participle.

${ }^{20}$ Andrew Nevins and I elicitated the following judgements with our informants.
(i) Dun hät (*oaft) küüt hai sij walach rijra
Then.past has (often) could.ptc he his horse ride.inf
(ii) Dun hät (*oaft) müst papa sou seir loupa ...
Then.past has often must.ptc dad so fast run
(elicitated)

(elicitated)
} 
jointly undergo movement to the V2 position. The structure is as in (21). ${ }^{21}$

$$
[\mathrm{CP} \mathrm{XP}[\mathrm{V} 1 \cdot \mathrm{V} 2][\mathrm{TP} \mathrm{SU} \ldots[\mathrm{V} 1 \cdot \mathrm{V} 2] \ldots . .
$$

The question arises what allows this clustering structure in Brazilian Pomeranian and disallows it in all other continental varieties. It is natural to assume that in Brazilian Pomeranian the $\mathrm{V} 1 \bullet \mathrm{V} 2$ cluster has been formed, and has automatically and unavoidably undergone head-movement to $\mathrm{C}$, while this is not possible in Frisian. It would be attractive to attribute this to another difference between Frisian and Pomeranian: the presence of HM-type of VPR in Pomeranian and its absence in Frisian. But if cluster-V2 is a consequence of any VPR, we would expect it to be present in West-Flemish and Alemannic as well, contrary to fact.

So now a natural solution shows up. As we have two competing theories of VPR, a head-movement account and an extraposition account, it is attractive to see these two theories not as two competing theories of VPR, but as describing two variants of VPR. So let us assume that Brazilian Pomeranian opts for the head-movement realization (17a), while Alemannic and West-Flemish opt for the extraposition account (17b), as elaborated in Van Riemsdijk (2002). We then immediately explain that a verbal cluster of the modal and the dominating perfect auxiliary is formed in Pomeranian: AUX•MOD, but not in Alemannic and West-Flemish. If V2 has to apply for independent reasons, this head, which is a complex head, moves jointly to the V2 position. In Alemannic and West-Flemish no such complex head is formed, as the complement VP undergoes raising to the modal. This occurs in a lower domain that is disconnected from the V2 operation. Similarly, the difference in nature of the modal is accounted for automatically as well. Only in the true VPR, which is an XPextraposition operation, the head into which the VP adjoins may not be complex, i.e. it may not be a gerund $(\mathrm{V}+\mathrm{n})$ nor a participle $(\mathrm{ge}+\mathrm{V})$. Only a simple infinitive suffices. This is the IPP effect (Hoeksema 1980, Van der Wyngaerd 1994, IJbema 1997). ${ }^{22}$

Let us finally show that the option chosen in Brazilian Pomeranian can be related to its weak T. As we have seen in section 2, Brazilian Pomeranian has a weak $\mathrm{T}$ in the sense that even nonfinite $\mathrm{T}$ must move to $\mathrm{C}$, incorporate into it, and form a stronger $\mathrm{C}+\mathrm{T}$ complex. This also occurs if a perfect auxiliary selects a TP. It is too weak to stand alone. This shows up in the form of the complementizer taum that is composed of a $\mathrm{C}$ and a $\mathrm{T}$ element. So, in three cases discussed above (the rise of taum, the specific head-movement type of VPR, and the cluster-V2), we see that a verbal head in a non-finite domain raises to a dominating domain. Notice that Alemannic must have a similar weak T in view of the similar movement of the $z u$ prefix to C, cf. (10). The question is, therefore, why Alemannic does not show the headmovement type of "VPR". In the next section we will show that Alemannic has another strategy of resolving weak $\mathrm{T}$.

\footnotetext{
${ }^{21}$ A similar phenomenon happens with reflexive pronouns, as illustrated in (i).

(i) Jeira dag [gript sich] hai air küüka.

every day fetches REFL he a chicken

'Every day he fetches himself a chicken'
}

$(\mathrm{UmL} 112)$

One might of think of Portuguese influence of enclitic SE, were it not that Brazilian Portuguese lacks enclisis in the spoken language. If Slavic influence is involved, the cluster-V2 should originate from Europe.

${ }^{22}$ Only Yiddish escapes the observed connection between the IPP effect and having the ge-prefix (Schmid 2005). This can be attributed to the other type of "VPR" namely by VR parallel to Pomeranian. This would predict that Yiddish has V2 of clusters as well. I do not know if this is the case as the data in the literature in (i) are not conclusive. Only inversion data suffice.

(i) Zey hobn gemuzt zikh farteydikn

(Schmid 2005:137)

they have.pl must.ptc REFL defend 


\title{
5. Downward resolutions of weak $\mathbf{T}$
}

Alemannic has the curious property of doubling the verb 'go', and some other aspectual verbs, in inifinitival contexts. Some examples are given in (22) taken from Van Riemsdijk (2002).

\author{
Alemannic \\ Si gaat de zmittag go (ge) choche \\ she goes the lunch VIM (vim) cook \\ 'She is going to cook lunch'
}

(Van Riemsdijk 2002:154)

This type of doubling occurs with gaa go', choo 'come', laa 'let' and aafaa 'begin'. Various accounts have been proposed for this, such as being a directional preposition (Lötscher 1993), or as a complementizer (Salzmann 2013), which puts it on a par with um 'for'. Van Riemsdijk (2002) calls it a verbal infinitive marker, which puts it on a par with $z u$ 'to'. A true verbal approach is adopted in Brandner \& Salzmann (2012). Whatever their status, it is clear that these elements sit in head positions within the verbal extended domain. In (23) we show the various positions where gaa may sit, taken from Brandner \& Salzmann (2012:69).

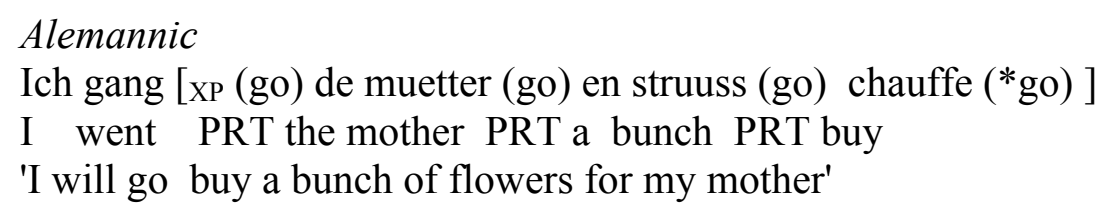

We added the extra starred $\left(*^{\text {go }}\right)$ at the utmost right edge of the domain to show that $g o$ is not really verbal. ${ }^{23}$ It is not immediately clear what the label of the domain indicated by XP should be. In Dutch the verb gaan may select either a CP as in (24a), or a TP as in (24b).
Dutch
a. Ik ga naar de stad om een bloemetje voor mijn moeder te kopen
I go to the city for a flower.DIM for my mother to buy
'I go to town to buy a flower for my mother'
b. Ik ga een bloemetje voor mijn moeder kopen
I go a flower.DIM for my mother buy.inf
'I go buy a bunch of flowers for my mother'

The construction in (23) parallels (24b). It is this construction that has verb raising and - in Flemish - verb projection raising and hence the various positions of 'go' in Flemish. We, therefore, assume that the Alemannic (23) has a complement TP. In function of the selecting verb ('go', 'come', 'let', 'begin'), the particle is selected. In (25) we show a few clear examples taken from Van Riemsdijk (2002:154).
Alemannic
a. Si gaat de zmittag go (ge) choche she goes the lunch VIM (vim) cook 'She is going to cook lunch'

\footnotetext{
${ }^{23}$ In the domain-final position, true verbs are possible, illustrated in (i).

(i) Ich ha (wele) de muetter (wele) en struuss (wele) chauffe (wele)

I have will the mother will a bunch will uy will

'I wanted to buy a bunch of flowers for my mother'
} 
b. Si chunt de zmittag cho (ge) choche she comes the lunch VIM (vim) cook 'She is coming to cook lunch'

Apparently, the dominating aspectual predicate can 'see' internal positions within this embedded TP domain. Just as in the case of $z u$ which starts off as a infinitival prefix, we suggest that this go/cho/la/afa has the similar nature of a verbal prefix. Just as $z u$, this abstract particle moves up until it reaches the highest projection of its domain. If we assume that no $\mathrm{CP}$ layer is available in these constructions, we must assume that some other rescuing strategy is provided. Apparently the dominating aspectual verb imposes features onto the verbal particle movement chain. This shows up as a separate lexicalization, as go, cho, etc. As all intermediate positions are 'seen' by this chain, i.e. form part of this chain, lexicalization of the intermediate positions is possible in principle.

\section{Daua support}

Pomeranian has a very recurrent strategy of using periphrastic do-constructions ("dosupport"). In those cases, a finite lexical verb is replaced by a finite form of daua + the infinitive-I of the lexical verb. In Brazilian Pomeranian it occurs abundantly in embedded clauses, and also in main clauses. In main clauses, however, it is not really periphrasis, as daua behaves like a modal verb, as in (28abc) ${ }^{24}$ In (28c) and (28d), the construction imports a habitual or a durative reading.

\section{Brazilian Pomeranian}

a. Un wat dar nog is, daua sai ni meir forköipa And what there still is, do they not anymore sell.inf 'and what is still there, they may not sell anymore'

b. ik dau ni stella I do not steal.inf 'I may not steal'

c. Dat ypsilon daua wij ni oft benutsa bijm srijwen
The 'y' do.pl we not often use.inf upon-DAT write.gerund 'we need not often use ' $y$ ' in writing'

d. (Context: why is this book here on the table?) ik dee dat lè:sa I did that read.inf 'I was reading it'

$(\mathrm{UmL}: 87)$ modal reading modal reading durative reading

In these cases, there are complementary effects with true modals, as illustrated in (29).

\section{Brazilian Pomeranian \\ *ik dee dat bauk lä:sa muiden/muida \\ I did that book read.inf must.gerund / inf \\ 'I must read that book'}

Daua has turned into a pure auxiliary in Brazilian Pomeranian. It belongs to the 10 most frequent lexemes in this corpus, among other highly frequent items such as pronouns, articles, and coordinators. The 30 most frequent lexemes are all functional words and auxiliaries.

\footnotetext{
${ }^{24}$ The modal reading seems to be connected with negation, compare English 'need'. I do not know how systematic this behaviour is.
} 
Furthermore, there are no lexical uses of daua in this corpus. ${ }^{25}$ English lexical 'do' is rendered by måka.

In embedded clauses the situation is quite different. Daua is used without durative import. Daua-support in embedded contexts is, hence, more similar to English $d o$-support. It is a pure dummy that is optional in the present tense. (For the past tense, see section 9.2). It especially occurs in relative clauses and in temporal and conditional clauses, i.e. under the passe-partout relative pronoun wat, under wen 'when' and as 'if'. Some cases are given in (30).

\section{Brazilian Pomeranian}
a. Dai lüür wat kaina stampklots kena daua, ...
(UmL : 72)
the people that no grinding stick know do.pl, ...
'the people that do not know grinding sticks'
b. Un dat rad dreigt dai moil, wat dai mijlcha måla däit
$(\mathrm{UmL}: 75)$
and that wheel drives the mill, that the corn grind.inf does'
and that wheel drives the mill, which grinds the corn'
c. Wen man farijn måka däit, den kümt dår air wit wåter ruuter. (UmL : 56) when one farinha make.inf does, then comes there white water there-out 'when one makes farinha, white water comes out'
d. Soulang as sai upm nest sita daua,...
As long as thet on-the nest sit.inf do.pl, ...
'as long as they sit on the nest...'
e. wail dai meista lüür dai kircha un dai praisters mithelpa daua. (UmL : 80) because the most people the church and the priest with.help.inf do.pl
'as most people help the church and the priests'

If we assume that conditional and temporal clauses are relative clauses (Arsenijevic 2009, Haegeman 2009), we may say that embedded daua-support occurs in relative clauses. Summarizing, in Brazilian Pomeranian, daua has developed into a auxiliary and behaves syntactically like an auxiliary. It does not allow for modal stacking, just like its closest kin schåla 'shall' and muida 'must'. Finally, no gerund forms are found, *dauen, just like the modal verbs (*schålen/*koinen/*muiden), a pattern parallel to copular and aspectual auxiliaries, sin 'be' ${ }^{26}$, häwa 'have', and the passive auxiliary waara. This cannot be attributed to morphology, so we must look for a syntactic reason of the use of daua in embedded clauses. This is the subject of the next section.

\section{Interaction of $\mathrm{C}$ and daua}

In this section we investigate the interaction between the $\mathrm{C}$ of relative clauses and the dummy auxiliary daua. Why is it inserted? Notice that in all relative clauses (apart from subject relative clauses), the features that are sitting in $\mathrm{C}$ are distinct from the features on the inflected verb, which are coindexed to the subject. If so, it implies that when a weak $\mathrm{T}$ would move up to $\mathrm{C}$, a feature clash would arise. This would turn all relative clauses (apart from subject relative clauses) ungrammatical, unless some resort strategy is found to strengthen $\mathrm{T}$. Let us

\footnotetext{
${ }^{25}$ Two lexicalized gerunds are used: gaud im dauen 'in good financial shape' and grouddauwen 'greatdoing', 'ostentation'.

${ }^{26} \mathrm{Sin}$ 'be' is the only infinitive in $-n$, i.e. it has already the shape of a gerund. This might lead to a case of morphological blocking. Häwa 'have' does have a gerund but only in its lexical meaning: Taum eer klaina häwen; taum eer jonge häwen 'for them to have their youngsters' (2x), taum meir guisa häwen 'for them to have more geese'. Waara has a gerund in its copular use 'become': taum dik waaren 'in order to become thick'.
} 
assume that daua-support realizes this resort strategy to rescue the weak $\mathrm{T}$ of Brazilian Pomeranian. This means that daua insertion is complementary to other strategies to rescue weak $\mathrm{T}$, i.e. all configurations where $\mathrm{T}$-to-C movement applies, most specifically lexicalization of $\mathrm{C}+\mathrm{T}$ as taum. This turns out to be correct: no case was found with * $[$ taum ... dauen]. This is rather remarkable as daua occurs very frequently in the corpus (more than 150 times), while gerunds have a typical share of $20 \%$ of other verbs). ${ }^{27}$ Moreover, it is not the morphology of dauen that is in itself ill-formed, as the lexicalized gerund grouddauen 'greatdoing' shows, but its realization under complex complementizers.

Similar reasoning applies to perfect auxiliaries sin 'be' and häwa 'have'. Though [taum ... häwen] occurs three times in the corpus as lexical verb, illustrated in (31), it is ungrammatical with häwen as auxiliary verb.
Brazilian Pomeranian
a. taum eer klaina häwen
(UmL : 77)
for-to their small have.ger
'for them to have youngsters'
b. taum eer jonge häwen
for-to their young have.ger
'for them to have more youngsters'
c. taum meir guisa häwen
for-to more geese have.ger
'for them to have more geese'
(UmL : 78)
(UmL : 34)

We conclude that there is an incompatibility between taum in $\mathrm{C}$ and the presence of auxiliaries sin, häwa and daua. We have also seen in section 4 that the modal auxiliaries participate in chain formation with $\mathrm{C}$. As expected, $[$ taum ... modal $+n]$ is excluded as well: not one gerund of the modals is encountered. This gap is easily explained if daua and [taum ...] are both strategies for lexicalizing weak $\mathrm{T}$; there is no reason (and in fact no mechanism by which) to employ both.

\section{West Flemish and Verb Projection Raising}

The attentive reader might raise a question here: we essentially used the head movement approach to "Verb Projection Raising" of Haegeman (2007), represented in (17a), and applied it to Pomeranian. The assumption of this head movement could account for a cluster of properties in Pomeranian. But we also claimed that this head movement did not happen in West-Flemish. If we are right, West-Flemish must have the XP movement variant of "VPR". Do, then, all arguments that Haegeman presented still hold? If not, this head movement would be an ad hoc stipulation invented to explain Brazilian Pomeranian. If they do hold, how can we say that West-Flemish does not have this head movement?

Fortunately the contradiction is only apparent. As Haegeman crucially observes, this head movement is only available for inflected verbs, not for infinitives. Consider the paradigm in (32), taken from Haegeman (2007, 27-28).
West-Flemish
a. da Valère nie (en-oa) [willen dienen boek lezen] *(en oa)
that Valere not NEG-had [want.inf that book read.inf] NEG-had

\footnotetext{
${ }^{27}$ This is a rough estimation on the basis of the three most frequent lexical verbs in the corpus: måka måken (60 24), kooka kooken (28 4), planta planten (18-1). Notice that the percentage of gerunds increases with frequency.
} 
b. $\quad *$ Mee Valère nie te $(*$ een) [willen no Gent goan] (een) with Valere not to have [want.inf to Gent go.inf] have

In (32a) we see that the finite form oa 'had' obligatorily moves out of its base position (which is head-final) to a position in the middle field. In infinitival constructions, on the other hand, this does not happen (32b). Haegeman argues that the inflected nature is crucial for this "movement to F". If $\mathrm{V}$ is overtly inflected, be it by a past tense marker or a negative clitic, this movement is obligatory. If it is not overtly marked, it preferably remains in its base position, as happens in present tenses without a negative clitic. However, movement is not completely blocked. With infinitives this movement is blocked. ${ }^{28}$ So, for Haegeman this "movement to $\mathrm{F}$ " only occurs to the hierarchally highest form in a verbal cluster, $\mathrm{V}_{1}$. Haegeman does not discuss what happens in the case of head projection with infinitives as $V_{2}$. This definitely happens, as can be seen from the very same sentences, i.e. from the part between square brackets in (32), repeated here as (33):
a. [willen dienen boek lezen]
[want.inf that book read.inf]
'want to read that book'
b. [willen no Gent goan]
[want.inf to Gent go.inf]
'want to go to Gent'

In these substructures, willen 'want' is the highest verb, and -- in view of the head-final nature of West Flemish -- might have moved out of its base position, as in (34).
a. willen [dienen boek lezen] willen
b. willen [no Gent goan] willen

If we want to retain Haegeman's generalization that "head movement to $\mathrm{F}$ " only applies to finite forms in West-Flemish, we must conclude that (34) is not the correct analysis. Instead, the VP [dienen boek lezen] and the VP [na Gent goan] must have undergone VPR of the XPtype, as represented in (35).
a. [dienen boek lezen] willen [dienen boek lezen]
b. [no Gent goan] willen [no Gent goan]

In this way, it is guaranteed that willen and the higher inflected verb will never form a cluster in West-Flemish, so that the finite form will - in main clauses - undergo V2 alone, not as a cluster. We therefore can use Haegeman's head movement approach as a structural option. In West Flemish it only applies to finite forms, not to infinitives. In Brazilian Pomeranian it applies to participles as well. It would be outside the scope of this paper to tie this further to the various morphological realizations and/or to the IPP effect.

\section{Infinitival clauses and finitive clauses in Pomeranian \\ 9.1. Absence of $V$-to- $T$ in infinitival clauses}

Pomeranian has T-to-C in main clauses (this is the V2-effect). In this respect, Pomeranian fully parallels continental West-Germanic. But, as we have argued in the previous sections,

\footnotetext{
${ }^{28}$ The ambiguous nature of the grammaticality judgements with present tense forms might be due to the identity between the infinitive and at least three forms of the present paradigm $(1 \mathrm{sg}, 1 \mathrm{pl}, 3 \mathrm{pl})$.
} 
Pomeranian also has T-to-C in embedded infinitival taum clauses: taum lexicalizes $\mathrm{T}+\mathrm{C}$. This implies that the embedded lexical verb does not move to $\mathrm{T}$ in taum clauses. If $\mathrm{V}$ had moved to $\mathrm{T}, \mathrm{V}$ would be dragged to the $\mathrm{C}$ position as well, which is not what we see. There is material intervening between $\mathrm{C}(\mathrm{tau}+u m)$ and the clause final verb (buugen).
Brazilian Pomeranian
taum sich eir huus buugen
forto himself a hous build-en
'to build a house for himself'

So why needn't V move up to T? And is there independent empirical evidence that V remains in situ?

Let us start with the theoretical question. What helps $\mathrm{V}$ to be tense-linked without movement in Pomeranian? We will sketch an explanation along the lines of Pesestsky \& Torrego 2001 (P\&T). As P\&T show, head movement for the sake of tense-linking interacts with the behaviour of the subject. Let us briefly summarize P\&T's claims. Crucial in their model is the reinterpretation of the well-known subject-object asymmetries in English and Belfast English (BE), listed in (37) - (39).
a. Who *did [ - read the book]?
(subject)
b. What did [Mary read -]?
(non-subject)
a. Who did John say *did [ - loves Mary]? Belfast (subject)
b. Who did John say did [Mary love - ]? Belfast
a. Who do you say *that [ - read the book]]?
(non-subject)
b. What do you think that [Mary read
(subject)
(non-subject)

While extraction of a non-subject creates a complementizer element did and that, extraction of a subject blocks such an element (37, cf. Koopman 1983), blocks do-support in Belfast English (38, cf. Henry 1995), and causes that-trace effects (39, cf. Perlmutter 1971). P\&T assume that these complementizer elements $d o$ and that are complex: they spell out $\mathrm{T}+\mathrm{C}$. P\&T also apply their theory to infinitival clauses. P\&T identify Modern English for as a lexicalization of $\mathrm{T}+\mathrm{C}$, while to is in some other position. They study the following contrast.

(40) a. Sue would like [ PRO to buy the book]

b. Sue would like [*for PRO to buy the book]

Modern English to is, therefore, different from Middle English to, that we studied in section 2 and where to does undergo T-to-C movement, creating the complex complementizer forto. In Modern English PRO is incompatible with for, i.e. with T-to-C. P\&T capture this generalization, which they call the C-PRO correlation.

$$
\begin{aligned}
& \text { C-PRO correlation (P\&T 2001: 395) } \\
& \text { No T-to-C when the subject is } \mathrm{PRO}^{29}
\end{aligned}
$$

Let us now turn to Pomeranian. Pomeranian control constructions, such as modal verbs (42ab), and aspectual verbs (43ab), but also verbs like fersuika 'try', do not use taum, but a complementizer-less infinitival construction (44ab).

\footnotetext{
${ }^{29}$ The formulation in P\&T 2001 involves formal minimalist features:

(i) $\quad$ uT on C does not have the EPP property when the subject is PRO
} 


\section{Gertuan Postma}
Brazilian Pomeranian
a. ik wi [PRO aira na hus komma]
I want early to house come
b. ik wi [*taum PRO aira na hus kommen]
I want to early to house come.gerund
'I want to come home early'
(43) a. Wen mijlchatijd is, den gåa sai [PRO ala t'houp steela]
when corn-time is, then go.pl they [PRO all together steal.inf]
b. Wen mijlchatijd is, den gåa sai [*taum PRO ala t'houp steelen ]
when corn-time is, then go.pl they [ to PRO all together steal.inf]
(44) a. ik fersuik es [PRO aira na hus goa]
'When it is harvest time, they all go and steal together'
b. ik fersuik es [*taum PRO aira na hus goan]
I try it to early to house go.gerund
'I try to come home early'

As we know, the controlled element in the embedded infinitival clauses is always the embedded structural subject. Curiously, taum-clauses typically have a generic structural subject rather than a controlled subject, while some non-subject is controlled, as is illustrated in (45). In (45ab) the controlled element is extracted from an instrumental PP.
Brazilian Pomeranian
a. Man kan gruuwa darfon stampa urer mala lata $\left[\mathrm{PRO}_{\mathrm{i}}\right.$ taum $\mathrm{PRO}_{\text {arb }}$ küüken mit $\mathrm{t}_{\mathrm{i}}$ futra]. One can groats thereof thrash or mill let [ for-to chicken with (it) feed] 'One can grind it or have it milled to groats to feed the chicken with it'
b. Dai twai letsta sorta sin dai besta $\left[{ }_{\mathrm{CP}} \mathrm{PRO}_{\mathrm{i}}\right.$ taum [ $\mathrm{PRO}_{\text {arb }}$ gumimelk [ $\mathrm{t}_{\mathrm{i}}$ ruuter] måken]] The last two types are the best [C $\mathrm{PRO}_{\text {rel }}$ for-to [те PRO gum milk from $\mathrm{t}_{\text {rel }}$ make]] 'The last two types are the best to extract gum milk from it'

This other argument, indicated with $\mathrm{PRO}_{\mathrm{i}}$ in (45), can be clearly syntactically projected as in the two examples above, or be more implicit, as in (46abc) below. In (46a), an implicit instrumental argument seems to be controlled by the matrix subject deis böim, in (46b) it is a locational argument "somewhere", in (46c) it is a temporal argument "already now".
Brazilian Pomeranian
a. Deis böim koina wij benutsa [taum $\mathrm{PRO}_{\text {arb }}$ feel sachen maken] these trees can we use forto many things make 'We can use these trees to make many things (with them/out of them)'
b. Taum bataada planta mud dat land sandig sin Forto patatoes plant.inf must the land sandy be 'For one to plant patatoes (somewhere), the land (there) must be sandy'
c. Duu büst ni ni grout naug taum air Flasche Wiin drinken you are yet not big enough forto a bottle of wine drink.ger 'you are not big enough to drink a bottle of wine (already now)'

The same is true for English. But while English can have a pure control-reading and the $\mathrm{PRO}_{\text {arb }}$ reading + implicit control, Pomeranian only has the $\mathrm{PRO}_{\text {arb }}$ reading. In the case of real control, taum is excluded. We, therefore, have the scheme in (47) for Pomeranian: if there is 
control, there is no taum; if there is taum, there is no control. If we identify taum (which is $\mathrm{C}+\mathrm{T}$ ) with $d o$ and that in English, the scheme parallels the paradigms in (37)-(40) by P\&T.
Brazilian Pomeranian
a. ik fersuik es $\left[\mathrm{PRO}_{\mathrm{i}}\right.$ *taum [ $\mathrm{t}_{\mathrm{i}}$ aira na hus goa(n)] I try it early to house go.inf
b. $\quad \mathrm{NP}^{\alpha} \ldots\left[{ }_{\mathrm{CP}} \mathrm{PRO}_{\mathrm{i}}{ }^{\alpha}\right.$ taum $\left[{ }_{\mathrm{TP}} \mathrm{PRO}_{\text {arb }}\right.$ gumimelk [ $\mathrm{t}_{\mathrm{i}}$ ruuter $]$ måken $\left.]\right]$ (non-subject)
a thing forto gum milk [ out of - ] make.inf2
(subject)

Notice that (47) copies the P\&T's C-PRO correlation given in (41). This correlation is a restatement of the finding that taum $(=\mathrm{T}+\mathrm{C}$, i.e. "+EPP") disallows for control of the embedded subject. Then, Pomeranian chooses for T-to-C (lexicalized as taum), while the sister languages chooses for fronting the subject. These sister languages lack the complex taum complementizer in infinitival constructions. Since West Germanic has generally T-to-C in main clauses and finite embedded clauses (P\&T 2001), the status of subject PRO in infinitivals must be the factor that distinguishes Pomeranian from the rest of West Germanic. Apart from this generalization, there is the generalization that taum always is accompanied of the verb in the en-form. We list the generalizations in (48).

(48) Empirical generalizations in Pomeranian

- taum only when the verb is marked with $-n$

- control only in the absence of taum

- PRO resides low (not in specTP)

This brings us to the structures in (49). For both variants, we have a standard syntactic structure with a head-final VP, embedded in a $v$ P (Chomsky 2005), which is also head final. The choice for a head-final structure is not crucial, it only facilitates the representation. This $v \mathrm{P}$ is embedded into a head final TP structure and a head initial CP structure. We have inserted zu/tau in T and $u m$ in C. These are all standard choices. The only distinction is the presence of an $-n$ morpheme in Pomeranian. We have inserted it in $v^{\circ}$. We then can explain the absence of -en forms of auxiliaries (section 7), *dauen/*muiden/*schålen, under the assumption that auxiliaries insert outside $v$ P. Let us first discuss German. In German, $\mathrm{T}$ is strong, so the verbal projections end up in $\mathrm{T}$ by subsequent head movement (arrows 1+3). As $\mathrm{T}$ is strong, it does not move. Instead, the subject takes care for the tense licensing (arrows $2+4)$. 


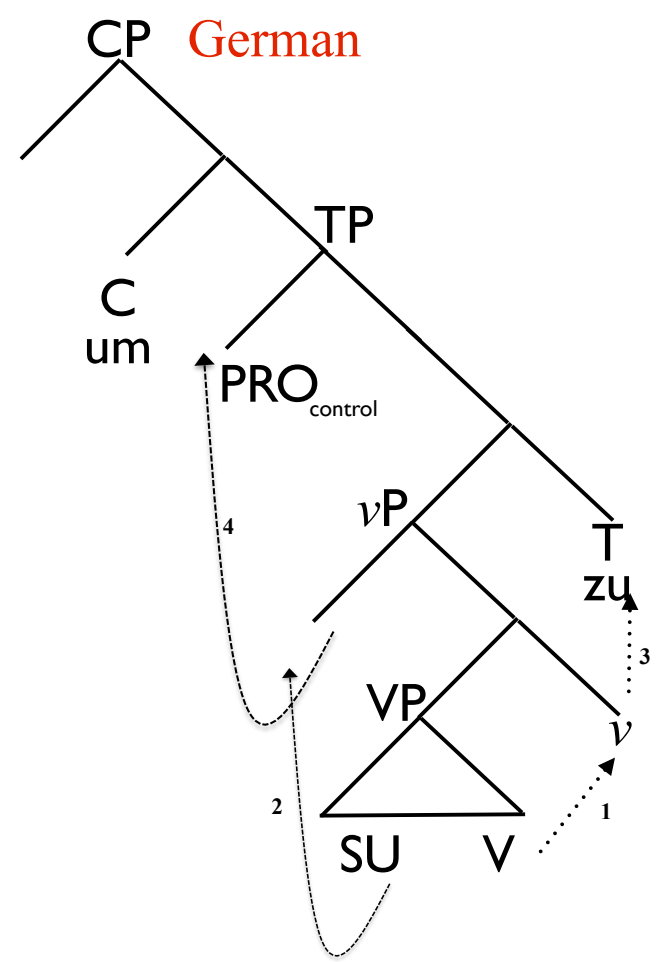

(49)

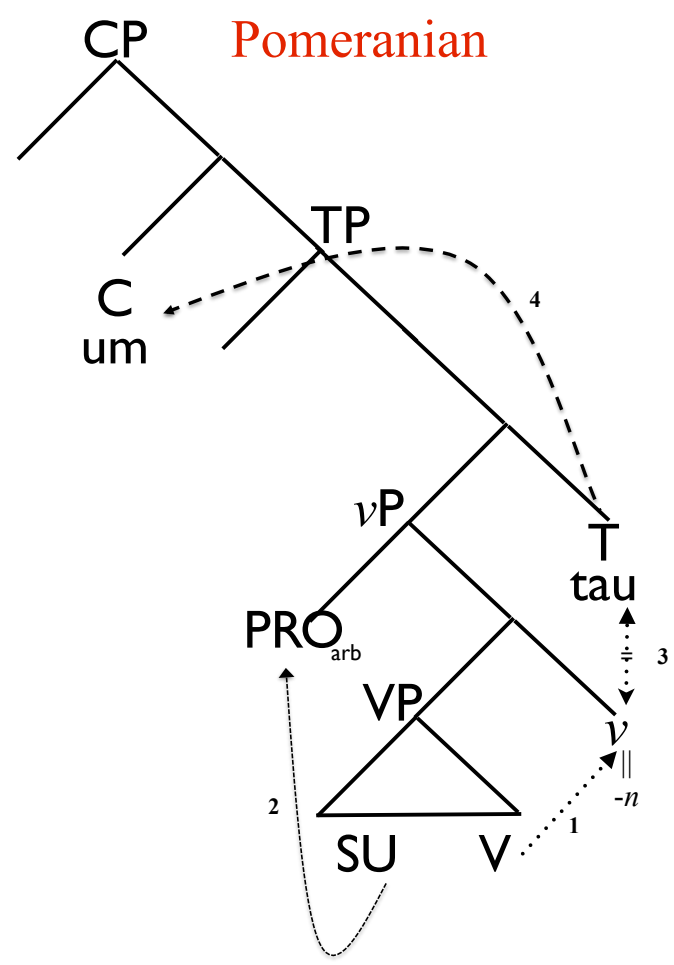

b.

In Pomeranian, on the other hand, $\mathrm{T}$ is not strong but the lower $v$ head, lexcialized by the n-morpheme. So the verbal head raises until $v^{\circ}$ (arrow 1). $\mathrm{T}$ is weak and ends up in $\mathrm{C}$ (arrow 4). We also indicated the separation of the $v$ domain and the T domain in Pomeranian by the blocked arrow 3. To explain the rise of taum in Pomeranian infinitival clauses, and its absence in its sister languages, we assume that the subject is not available for tense-linking in Pomeranian ("cannot be probed by C"), while it is probable in the sister languages of WestGermanic, German and Dutch. We therefore assume that the subject remains low in specvP. Presumably, it sits in its specifier and $v^{\circ}$ maintains a special a spec-head agreement relation. If so, the $-n$ morphology licenses the empty pro-subject in specvP. It is not controlled from outside, so it gets an arbitrary interpretation. As the subject does not raise to specTP, the tense-linking must be done by T-to-C. This shows up as taum. Notice that we need an auxiliar hypothesis that $v^{\circ}$ gets an in-situ tense-licensing (blocked arrow 3).

(50) a. The PRO subject undergoes XP-movement in German for tense-linking

b. $\quad$ The T-head underhoes head-movement in Pomeranian for tense-linking

c. $\quad v^{\circ}$ is weak in German and raises to $\mathrm{T}$

d. $\quad v^{\circ}$ is strong in Pomeranian and is licensed in situ without movement

e. The subject PRO/pro cannot be controlled by the matrix clause in Pommeranian taum-clauses.

The theory of Pesestky and Torrego account for (50abe). The challenge is, therefore, to tie the seemingly independent properties (50cd) to $P \& T^{\prime} s$ tense feature dimension through an independently motivated feature calculus. It is probably that the link between both (49abe) and $(49 \mathrm{~cd})$ is the relation between the low subject in Pomeranian and the lexical nature of $v$ in Pomeranian. We refer to Postma (forthcoming) for a formal account. In this data-oriented study, we limit ourselves to an extra empirical argument for the in situ licensing of $v^{\circ}$ in Pomeranian, i.e. for the blocked movement relation between $v^{\circ}$ and T. 


\subsection{Absence of $V$-to- $T$ in finite clauses in Pomeranian}

As we have seen in the previous section, an important difference between Pomeranian and German is that $\mathrm{V}$ moves out of $v \mathrm{P}$ and goes further up to $\mathrm{T}$ in German, but $\mathrm{V}$ remains within $v \mathrm{P}$ in Pomeranian. That is the reason that taum is created in Pomeranian. We derived this result for infinitival clauses, but absence of V-to-T seems to be a more general property of Pomeranian. Pomeranian has a strong tendency to use periphrastic constructions ("dosupport"), especially in embedded clauses (section 6). Moreover, cluster V2 (discussed in section 4) does not occur with lexical verbs. This indicates that lexical verbs do not enter the $\mathrm{T}$-domain. In this section, we provide a further argument for absence of V-to- $\mathrm{T}$.

Brazilian Pomeranian has, just like its West-Germanic sister languages, two types of verbs: 1. verbs that form derived tenses by suffixation (-ed morpheme, work-worked-worked), the so called 'weak verbs', illustrated in (51a-e), and 2. the verbs that display root alternation (Eng. fall-fell-fallen), the so-called 'strong verbs', illustrated in (51f-j). Curiously, past tenses of the regular verbs are absent in our corpus, while for the irregular verbs the preterit does occur and does so abundantly. ${ }^{30}$

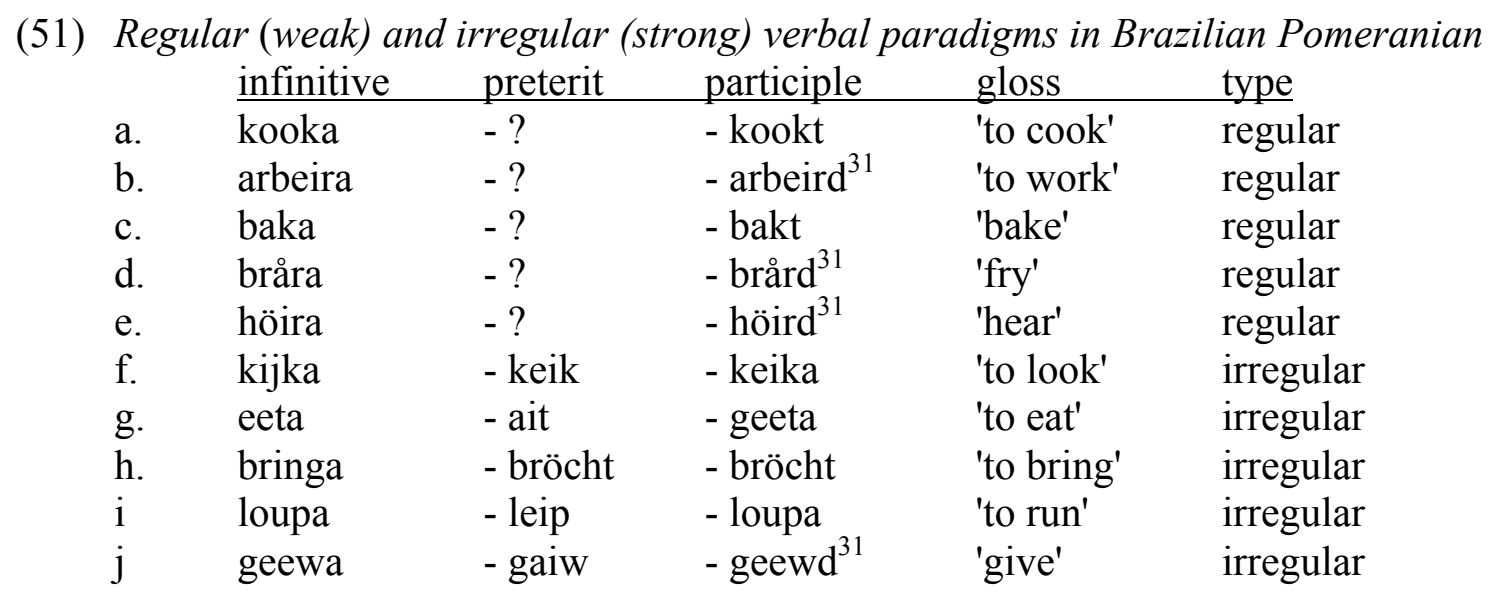

Etymologically expected preterit forms like kookt(a) 'cooked' and arbeird(a) 'worked' do not occur. The hole in the paradigm is filled by periphrastic constructions, i.e. the past tenses are circumscribed by either perfect auxiliary + participle (with a past tense reading) as in (52a) or by daua.past + infinitive, when the main verb is regular, illustrated in (52bc). So, the regular class of verbs has developed a morphological defectiveness in the past tense. ${ }^{32}$
Brazilian Pomeranian
a. Dun häwa/*kookta wij ous seir oft rapadura kookt then hawe we us very often brown sugar cooked 'then we very often cooked us brown sugar'
b. Dai kiner däira/*fröigda sich fröiga wen .... the children did SE enjoy when ...
(regular)
(regular)

\footnotetext{
30 Praeteritum-schwund ("loss of the preterit") is a general property of South-German dialects, (Lindgren 1957), but strong and weak verbs do not diverge in those dialects (Jörg 1976). For a discussion of the possible causes, cf. Chang (2001). See also Abraham \& Conradi (2001).

${ }^{31}$ Particial ending -d has undergone final devoicing, when uninflected.

32 Anthony Warner reports on similar tendencies in the history of English. In Middle English, dosupport starts out earlier in past tenses than in present tenses, and earlier in weak verbs than in strong verbs (Warner 2009). The generalization is that an overt -ed morpheme is the trigger of suppletion by do-support.
} 


\section{'the children enjoyed it when ...' \\ c. un dat däir/*duurd lang duura \\ and that did long last \\ 'and that lasted long'}

(regular)

The strong class does not suffer form this problem, as illustrated in (53ab), though they may occur in periphrasis as well (53c).
Brazilian Pomeranian
a. Dai seegabuk laip upa weir the goat run.sg in-the meddow
(irregular)
'The goat walked in the meddow'
b. Früüer aita dai lüür dat gans jar oiwer blous mijlchabroud earlier ate.pl the people the whole year through only corn bread 'years ago, the people only ate corn bread the entire year'
c. Den däir sai wek håns uutsuika
(irregular)
then did she some hens select
'then she selected some hens'
(irregular)

Some originally weak verbs have turned into a semi-apophonic verb (54ab) in the past tense (måka-maik-måkt 'make', fråga-froug-fragt 'ask') or irregular (säga-säär-sägt 'say'). These do occur in the past tense in the corpus. Even the frequent verb jääwa 'give' (51j) has joined this half-irreglar class.
a. Darbij maik sai eer muul up
(irregular)
With that made.sg she her mouth open
'Then she opened her mouth'
b. un dai lüür wäira nijdlig un keika houg un frouga:...
and the people became angry and looked up and asked:...
(irregular)
c. Morgens säära dai bruirers: ... morning.inf said.pl the brothers: ...
(irregular)
'In the morning, the brothers said: ...'

To prove that the complete absence of regular past tenses in the corpus is not an accident, we did a statistical evaluation. As the corpus is not annotated, it was difficult to collect all the past tenses. For that reason, we did a base line statistics in a subset of the corpus, that was more easily created: all clauses with dun "then" were evaluated. Pomeranian dun ("when"), like Dutch toen, Frisian doe, requires a past tense. ${ }^{33}$ The present tense adverb is den/dan/dan 'then'. There are two relevant dimensions: 1 . the past tense is formed analytically (AUX +Ptc) or synthetically (PAST). 2. the verb is strong (by root alternation, apophony) or weak (suffixation, -ed). The cross table is given in (55).

\begin{tabular}{|l|l|l|}
\hline cross table & synthetic & analytic \\
\hline strong & 24 & 15 \\
\hline weak & 0 & 8 \\
\hline
\end{tabular}

The deviation from random of the empty cell of syntactic weak verbs is significant ( $p$ value $<0.0001$ ). In order not to reason exclusively ex absentia, we did an additional fieldwork,

\footnotetext{
${ }^{33}$ Even praesens historicum is not possible with toen in Dutch, only dan. I guess that the same is true in Pomeranian.
} 
where we elicitated hypothetical forms like sai kookta 'they cooked', by our two informants as well by Tressmann. They all rejected clauses like (56a) with a weak preterit, and accepted (56b) with a strong preterit.
a. *Jisten kookt hai sich eiger yesterday ccoked he refl eggs 'yesterday, he cooked himself eggs'
b. Jisten maik hai sich air sup yesterday made he REFL a soup 'Yesterday, he made himself a soup'

We therefore obtain the generalization in (57):

\section{Generalization}

No synthetic past tenses of regular verbs occur in Pomeranian

At first glance, the development of defectiveness in a regular class seems mysterious. However, if we assume that weak and strong forms are derived by a different syntax in gerenal, as in (58), we explain why the weak verbs in Pomeranian cannot form their past tense, provided that Pomeranian does not have V-to-T.

\section{Strong-weak opposition in verbs}

- A weak verb in Germanic must move to T to pick up its ed-morphology ${ }^{34}$

- A strong verb in Germanic need not move to T to pick up its morphology

- There is no V-to-T in Pomeranian

This confirms the specific property of Pomeranian found in taum constructions that $v^{\circ}$ disconnects from $\mathrm{T}$.

\section{Conclusions}

In this article we report on some fieldwork on a West Germanic language in the state of Espirito Santo in Brazil: Pomeranian. We presented new empirical data on its verbal system and compared it with the now extinct European Pomeranian, as well as with other variants of West Germanic (Frisian, West Flemish, Alemannic). We concluded that a cluster of properties of the Pomeranian verbal system could be attributed to its "weak T", i.e. some underspecification of the $\mathrm{T}$ head in Pomeranian. Just like European Pomeranian, $\mathrm{T}$ strives for resolution of this under-specification, and - in contrast to its European ancestors - does so overtly. What all variants of Pomeranian have in common, is that the licensing of this weak $\mathrm{T}$ is done at a phase level $\mathrm{C}$ both in finite and infinitival contexts. The cause of this weak $\mathrm{T}$ is the strengthened morphology at the $v \mathrm{P}$ level. This shows up in the $-n$ morphology in noncontrol contexts. The stronger $v$-head prevents $\mathrm{V}$ to move up to $\mathrm{T}$. The structure leads to T-to$\mathrm{C}$ resolution (taum), do-support, and the complete absence of regular past tenses in Pomeranian.

\footnotetext{
${ }^{34}$ West Flemish finite verbs move or don't move in function of their being overtly affixed or not, reported in Haegeman (1998) and briefly discussed in section 8. This also points into the direction of a distinct syntax of suffixal morphology.
} 


\section{References}

UmL - See Tressmann (2006a).

Abraham, Werner 2004. The Grammaticalization of the Infinitival Prepo-sition. Journal of Comparative Germanic Linguistics 7. 111-170.

Abraham, Werner \& Jac Conradi (2001). Präteritumschwund und Diskursgrammatik: Präteritumschwund in gesamteuropäischen Bezügen--areale Ausbreitung, heterogene Entstehung, Parsing sowie diskursgrammaische Grundlagen und Zusammenhänge. Benjamins. Amsterdam

Arsenijevic, Boban (2009). $\{$ Relative $\{$ Conditional $\{$ Correlative clauses $\}\}$ \}. In A. Liptak (ed.) Correlatives cross-linguistically. Elsevier, 131-157.

Bayer, Josef. (1984). COMP in Bavarian Syntax. The Linguistic Review 3, 209-274.

Bayer, Josef (1993). Zum in Bavarian and Scrambling. Linguistische Berichte Sonderheft 5, 1993, 50-70.

Bayer, Josef \& Ellen Brandner (2004). Klitisiertes $z u$ im Bairischen und Alemannischen. In: F. Patocka \& P. Wiesinger (eds), Morphologie und Syntax deutscher Dialekte und Historische Dialektologie des Deutschen. Wien: Edition Präsens.

H. Bennis (1986). Gaps and Dummies. Linguistic Models 9. Dordrecht: Foris Publications.

Hans Bennis \& Teun Hoekstra. (1984). Gaps and Parasitic Gaps. The Linguistic Review 4. 29-87.

Besten, Hans den and Jerold A. Edmondson. (1983). The Verbal Complex in Continental West Germanic. In: Werner Abraham (ed.). On the Formal Syntax of Westgermania. Amsterdam: Benjamins.

Besten, H. den und J. Rutten (1989). On Verb Raising, Extraposition and Free Word Order in Dutch, in: D. Jaspers, W. Klooster, Y. Putseys und P. Seuren (eds), Sentential Complementation and the Lexicon, Dordrecht, Foris. 41-56

Brandner, E. (2006). Bare Infinitives in Alemannic and the Categorial Status of Infinitival Complements. Linguistic Variation Yearbook 6, 203-268.

Brandner, E \& M. Salzmann (2012). Crossing the Lake - Motion Verb Consturctions in Bodensee-Alemannic and Swiss German. In Ackema et al. Comparative Germanic Syntax. The State of the Art. Amsterdam. 67-97.

Brokhaus (2012). Brokhaus Enzyklopädie. In 30 Volumes. Brokhaus Verlag.

Chomsky, Noam. (2005). The Minimalist Program. Cambridge, MA: MIT Press.

Chang, Shoou-Huey (2001). Der Rückgang des synthetischen Präteritums im Jiddischen kontrastiv zum Deutschen. Helmut Buske Verlag. Hamburg.

Ellegård, A. (1953). The Auxiliary Do: The Establishment and Regulation of its Use in English. PhD. dissertation, 1953).

Evers, Arnold. 1975. The transformational cycle of Dutch and German. Ph.D. Dissertation, University of Utrecht.

Evers, A. (1990). The Infinitival Prefix "zu" as INFL. In: G. Grewendorf und W. Sternefeld (eds). Scrambling and Barriers, Amsterdam, John Benjamins.

Franceschetto, Cilmar (2004). Dados Sociológicos da Imigração Suíça no Espírito Santo. In: Viagem à Provincia do Espirito Santo 1856 - 2004. Edição Comemorativa aos 148 anos da Imigração Suíça no Espírito Santo. Coleção Canaã. Vitória. 153-165.

Gelderen, Elly van (1993). The Rise of Functional Categories. Amsterdam: John Benjamins.

Gelderen, Elly van (1998). "For to in the History of English". American Journal of Germanic Language and Literature 10.1: 45-72.

Grimm, Jacob \& Willhelm (1854-1961). Deutsches Wörterbuch. http://woerterbuchnetz. de/DWB/

Haan, G. de (1987). 'De Syntacticus als Frisist'. In: S. Dyk \& J. Hoekstra (eds.), Ta de Fryske Syntaksis. Ljouwert: Fryske Academy. 57-80. 
Haegeman, Liliane (1998). Verb movement in embedded clauses in West Flemish. Linguistic Inquiry 29: 631-56.

Haegeman, Liliane (2007). Generatieve syntaxis en microanalyse van een dialect. Neerlandistiek.nl 07.02.

Haegeman, Liliane. (2009). The movement analysis of temporal adverbial clauses. English Language and Linguistics 13:385-408.

Haegeman, Liliane, and Riemsdijk, Henk van (1986). Verb Projection Raising, scope, and the typology of rules affecting verbs. Linguistic Inquiry 17: 417-466.

Haider, Hubert. (1993). Deutsche Syntax -- Generativ. Gunter Narr Verlag, Tübingen.

Haider, Hubert. (2003). V-Clustering and Clause Union - Causes and Effects. In: Seuren, Pieter A.M. and Gerard Kempen (eds.), Verb Constructions in German and Dutch. 91-126.

Hoeksema, Jack. 1980. Verbale verstrengeling ontstrengeld. Spektator 10, 221-249.

Hoekstra, Jarich (1992). Fering $t u$-Infinitives, North Sea Germanic Syntax and Universal Grammar, in: Volkert F. Faltings, Alastair G.H. Walker und Ommo Wilts (eds). Friesische Studien I [= NOWELE, Supplement 8]. Odense University Press, Odense, 99-142.

Hoekstra, Jarich (1997). Syntax of infinitives in Frisian. PhD dissertation Groningen University.

IJbema, Aniek. (1997). Der IPP-Effekt im Deutschen und Niederländischen. Groninger Arbeiten zur Germanistischen Linguistik 40, 137-163.

IJbema, Aniek. (2002). Grammaticalization and Infinitival Complements in Dutch. LOT Dissertation Series 54.

Jörg, Ruth (1976). Untersuchungen zum Schwund des Präteritums im Schweizerdeutschen. Tübingen.

Kayne, Richard S. (1999). Prepositional Complementizers as Attractors. Probus, 11, 39-73.

Koopman, Hilda. (1983). ECP Effects in Main Clauses. Linguistic Inquiry 14: 346- 350.

Koster, J. and R. May (1982). 'On the Constituency of Infinitives', Language 58, 117-143.

Lasnik, Howard (1995). Verbal morphology: Syntactic structures meets the Minimalist Program. In: Héctor Campos and Paula Kempchinsky (eds). Evolution and revolution in linguistic theory: Essays in honor of Carlos Otero, Washington (D.C). Gerorgetown University Press. 251-275.

Laude \& Dorries (1995). Hinterpommersches Wörterbuch des Persantegebietes. Cologne.

Lindgren, Kaj. (1957). Über den oberdeutschen Präteritumschwund. Helsinki.

Lötscher, Andreas. (1993). Zur Genese der Verbverdoppelung bei gaa, choo, laa, aafaa ("gehen", "kommen","lassen", "anfangen") im Schweizerdeutschen. In: Werner Abraham and Josef Bayer (eds). Dialektsyntax. Opladen: Westdeutscher Verlag. 180-200.

Müller, R. (1996). Historisch-vergleichende Studien zum Infinitiv im Friesischen. MA-thesis Eberhard-Karls University, Tübingen.

Mustanoja, Tauno F. (1960). Middle English Syntax. Helsinki: Société Néophilologique.

Perlmutter, David. (1971). Deep and surface structure constraints in syntax. New York: Holt, Rinehart and Winston.

Pesetsky, David \& Esther Torrego (2001). "T-to-C Movement: Causes and Consequences. In Michael Kenstowicz (ed.), Ken Hale: A Life on Language. Cambridge, MA: MIT Press.

Pesetsky, David \& Esther Torrego (2004). Republished as Pesetsky \& Torrego (2007).

Pesetsky, David, and Esther Torrego. (2007). The syntax of valuation and the interpretability of features. In Simin Karimi, Vida Samiian and Wendy Wilkins (eds). Phrasal and clausal architecture, Amsterdam: John Benjamins. 262-294.

Potsdam, Eric. 1997. English verbal morphology and VP Ellipsis. In: Kiyomi Kusumoto (ed.). Proceedings of the North Eastern Linguistics Society Annual Meeting 27, Amherst: GLSA. 353- 368. 
Riemsdijk, Henk van (2002). The Unbearable Lightness of GOing. Journal of Comparative Germanic Linguistics 5: 143-196.

Roberts, I.G. (1993). Verbs and Diachronic Syntax: A Comparative History of English and French. Kluwer.

Sabel, Joachim. (1996). Restrukturierung und Lokalität. Berlin.

Salzmann, Martin (2011). New evidence for postsyntactic verb cluster formation and a right-branching base order. Talk presented at NELS, Toronto.

Salzmann, Martin. (2013). New arguments for verb cluster formation at PF and a rightbranching VP. Evidence from verb doubling and cluster penetrability. Linguistic Variation 13.1, 81-132.

Schallert, Oliver (2012). Untersuchungen zu Ersatzinfinitivkonstruktionen in den Vorarlberger und Liechtensteiner Dialekten. PhD thesis. Universität Marburg.

Schallert, Oliver (2013). Control predicates in Alemannic. Talk presented at Workshop European Dialect Syntax VII, University of Konschtanz, June 18, 2013.

Schmid, Tanja (2005). Infinitival Syntax: Infinitivus Pro Participio as a Repair Strategy. Benjamins. Amsterdam.

Stritzel, Herbert. (1974). Die Gliederung der Mundarten um Lauenburg in Pommern. Deutsche Dialektgeographie; Berichte und Studien über G. Wenkers Sprachatlas des Deutschen Reichs, 33. - Marburg, 1937.

Tressmann, Ismael. (2006a). Upm Land - up pomerisch språk. Santa Maria de Jetibá.

Tressmann, Ismael. (2006b). Pomerisch-Portuguisisch Wöirbauck - Dicionário Enciclopédico Pomerano-Português. Secretaria de Educação, Santa Maria de Jetibá.

Tschudi, Johann Jakob de (1860). l'Envoyé extraordinaire au Brésil, Mr. de Tschudi, sur les colonies de Santa Isabel, Santa Leopoldina et Rio Novo, etc. (Du 20 Décembre 1860). In: Feuille Fédérale Suisse 13.

Tschudi, Johann Jakob de (1860). Reisen durch Süd Amerika.

Vanden Wyngaerd, G. V. (1987). Control Theory. PhD Dissertation, Antwerp University.

Vanden Wyngaerd, G. (1994). PRO-legomena. Distribution and Reference of Infinitival Subjects. Berlin: Mouton de Gruyter.

Visser, F.T. (1963). Historical Syntax of the English Language. Brill.

Vos, Marc de (2005). The syntax of verbal pseudo-coordination in English and Afrikaans. PhD Dissertation Leiden University.

Warner, Anthony (2009). DO in weak verbs in Early Modern English. Talk presented at 7th Workshop of SHES, Nijmegen, 6-7 June 2009.

Wiesinger, Peter (1983). Die Einteilung der deutschen Dialekte. In: Werner Besch et al. (Hrsg.): Dialektologie. Ein Handbuch zur deutschen und allgemeinen Dialektogie. Berlin/New York 1983. S. 807-900.

Wrede, Fred. (1895). Berichte über GWenkers Sprachatlas des deutschen Reichs. XII. Anzeiger für deutsches Altertum und Deutsche Literatur xxi. p. 260-296.

Wurmbrand, Susan. (2001). Infinitives: Restructuring and clause structure. Mouton de Gruyter (Studies in Generative Grammar 55). 